\title{
PENGEMBANGAN INSTRUMEN PENILAIAN BERBASIS HIGHER ORDER THINKING SKILLS (HOTS) PADA PEMBELAJARAN IPA TEMA SELAMATKAN MAKHLUK HIDUP KELAS VI SD
}

\author{
N.L. Julianti ${ }^{1}$, I.W. Lasmawan ${ }^{2}$, P.B. Adnyana ${ }^{3}$ \\ ${ }^{123}$ Program Studi Pendidikan Dasar \\ Universitas Pendidikan Ganesha \\ Denpasar, Indonesia \\ e-mail: julianti@undiksha.ac.id ${ }^{1}$, wayan.lasmawan@undiksha.ac.id ${ }^{2}$, \\ $\underline{\text { budi@undiksha.ac.id }}^{3}$
}

\begin{abstract}
Abstrak
Penelitian ini bertujuan untuk mengembangkan instrumen penilaian mata pelajaran IPA Berbasis HOTS (Kemampuan Berpikir Tingkat Tinggi) pada Tema "Selamatkan Makhluk Hidup" kelas VI SD. Penelitian dan pengembangan ini menggunakan model ADDIE yang terdiri dari 5 langkah, yaitu analyze (analisis), design (rancangan), development (pengembangan), implementation (implementasi) and evaluation (evaluasi). Subjek penelitian ini sebanyak 45 orang yang terdiri dari 2 akademisi (dosen), 3 praktisi (guru kelas VI) dan 40 siswa kelas VI. Ada dua instrumen yang digunakan, lembar penilaian kualitas produk dan kuesioner kepraktisan. Para akademisi memvalidasi instrumen yang digunakan dan menilai produk. Sedangkan kuesioner digunakan oleh guru untukmenilai kepraktisan produk. Data yang diperoleh selanjutnya dianalisis secara deskriptif dengan mencari nilai rata-rata dan pengujian reliabilitas instrumen menggunakan Alpha Cronbach. Selanjutnya, nilai rata-rata dikonfirmasi ke dalam tabel klasifikasi penilaian acuan patokan skala 5 dan koefisien alpha dikonfirmasi ke klasifikasi Guilford. Hasil analisis menunjukan a) produk yang dikembangkan terkategori sangat valid dengan skor 4,89, b) produk yang dikembangkan memiliki tingkat reliabilitas tinggi dengan nilai koefisien alpha 0,811 , dan c) produk yang dikembangkan memiliki tingkat kepraktisan sangat tinggi dengan skor 4,92. Dengan demikian, produk yang berupa instrumen penilaian IPA berbasis HOTS layak digunakan.
\end{abstract}

Kata Kunci : HOTS; Instrumen Penilaian, IPA

\begin{abstract}
This research aims at developing assessment tools based on Higher Order Thinking Skills (HOTS) on theme "save living things" for fifth grade of elementary school. This research and development used ADDIE model consisting of five stages, namely : analyze, design, development, implementation, and evaluation. Subject of this research was 45 people consisting of 2 lectures, 3 teachers of sixth grade and 40 students of sixth grade. There were two instruments used, assessment sheet for measuring quality of product and practical questionnaire. The lecturers validated the used instrument to assess product and to measure product quality. The students were used for field test. Meanwhile, the questionnaire was used to assess the product practicality. The obtained data were then analyzed with descriptive method by calculating the mean and Cronbach Alpha formula for reliability which were then being confirmed the mean into classification tabel of criterion referenced test with 5 classification and Guilford reliability classification. The analysis shows that a) the developed product is categorized into very valid with value of 4,89 , the developed product has high reliability with coeficient of 0,811 and the developed product has very high practicality with value of 4,92 . It means that the developed product in the form of assessment instrumen based on higher order thinking skill in natural science lesson is valid to used in the field.
\end{abstract}

Keywords : HOTS; Assessment Tool; Natural Science Lesson 


\section{PENDAHULUAN}

Dasar pembangunan sumber daya manusia adalah pendidikan. Menurut UU No 20 tahun 2003 tentang sistem pendidikan nasional, pasal 1 menyatakan bahwa pendidikan adalah usaha sadar dan terencana untuk mewujudkan suasana belajar dan proses pembelajaran agar peserta didik secara aktif mengembangkan potensi dirinya untuk memiliki kekuatan spiritual keagamaan, pengendalian diri, kepribadian, kecerdasan, akhlak mulia, serta keterampilan yang diperlukan dirinya, masyarakat, bangsa dan negara. Pendidikan memiliki andil yang sangat besar bagi terwujudnya kualitas sumber daya manusia yang berdaya saing tinggi. Untuk itu, penyelenggaraan pendidikan harus benar-benar diperhatikan agar mampu menjawab tantangan jaman.

Pemerintah Indonesia sudah menyiapkan beberapa kebijakan untuk terwujudnya pendidikan yang berkualitas. Salah satunya adalah melalui revisi Kurikulum 2013. Dalam kurikulum ini, siswa diminta lebih aktif selama proses pembelajaran melalui pendekatan saintifik. Dalam proses pembelajaran, siswa dipandang sebagai subjek yang aktif mengkonstruksi pengetahuannya. Dalam konteks ini, para guru berperan sebagai fasilitator yang memfasilitasi proses belajar siswa agar tujuan pembelajaran dapat dicapai. Muara yang diharapkan dari kurikulum ini adalah siswa yang memiliki keterampilan berpikir tingkat tinggi atau Higher Order Thinking Skills (HOTS) (Khotimah, $2018: 181$ ).

Kemampuan berpikir tingkat tinggi adalah cara berpikir kompleks yang tidak algoritmik dan menghasilkan banyak solusi (Barak dan Dori, 2009). Penekanannya adalah pada banyaknya solusi yang dapat diberikan pada suatu permasalahan. Kemampuan berpikir tingkat tinggi adalah terdiri dari kemampuan berpikir kritis, logis, reflektif, metakognitif, dan kreatif (King et al, 2011). Dalam taksonomi Bloom yang direvisi oleh Anderson and Krathwohl (2001), kemampuan berpikir tingkat tinggi mencakup kemampuan menganalisa (C4), mengevaluasi (C5) dan mencipta (C6).
Definisi-definisi tersebut menyiratkan bahwa kemampuan berpikir kritis identik dengan kemampuan pemecahan masalah atau problem solving.

Pembelajaran yang berbasis HOTS harus ditanamkan sejak dini pada semua mata pelajaran. Hal ini karena HOTS adalah kunci sukses dalam mengahadapi persaingan dalam abad 21 atau era globalisasi karena era ini penuh ketidakpastian sehingga perlu dikembangkan pemikiran yang kuat dan kritis dalam menyikapi permasalahan (Helmawati, 2019: 4). Selain itu pada abad 21, keterampilan berinovasi dan menguasai teknologi harus dimiliki oleh manusia (Chalkiadaki, 2018). Menurut Newman dan Wehlage (Widodo, 2013:162), seseorang yang memiliki kemampuan berpikir tingkat tinggi dapat membedakan ide atau gagasan secara jelas, berargumen dengan baik, mampu memecahkan masalah, mampu mengkonstruksi penjelasan, mampu berhipotesis dan memahami hal-hal kompleks menjadi lebih jelas. Hal ini tentu dapat membuat siswa mampu memecahkan permasalahan dalam hidupnya dengan baik.

Salah satu mata pelajaran yang mendapat identik dengan HOTS adalah IImu Pengetahuan Alam (IPA). Hal ini karena IPA adalah pengetahuan khusus yaitu dengan melakukan observasi, eksperimentasi, penyimpulan, penyusunan teori dan demikian seterusnya kait mengkait antara cara yang satu dengan cara yang lain (Abdullah, 1998: 18). Proses-proses itu sangat berkaitan erat dengan terbentuknya keterampilan berpikir tingkat tinggi. Keterampilan berpikir tingkat tinggi dalam pelajaran IPA telah menjadi tombak dalam perkembangan ilmu pengetahuan dan teknologi. Hal ini karena dalam IPA menekankan pada pada penguasaan konsep, fakta, prinsip dan proses penemuan (Sulistyorini, 2007: 39).

Agar hasil belajar IPA pada HOTS dapat diketahui dengan baik maka diperlukan sistem penilaian atau evaluasi yang baik. Sistem penilaian yang digunakan harus mampu memberikan informasi yang kelanjutan terkait hasil belajar siswa sehingga selanjutnya dapat 
dibuat keputusan (Sunarti dan Rahmawati (2014: 7). Ada tiga karakteristik instrumen penilaian berbasis HOTS, yaitu : (1) Menilai kemampuan berpikir tingkat tinggi; (2) Mengarah pada permasalahan konstekstual; (3) Soal yang digunakan beragam.

Pada kenyataannya, keterampilan berpikir tingkat tinggi siswa di Indonesia masih terkategori rendah berdasarkan peringkat Programme for International Student Assesment (PISA) tahun 2018 kategori kemampuan membaca, sains, dan matematika, skor Indonesia tergolong rendah karena berada di urutan ke-74 dari 79 negara. Pada kategori kemampuan membaca, Indonesia menempati peringkat ke-6 dari bawah (74) dengan skor ratarata 371. Turun dari peringkat 64 pada tahun 2015. Lalu pada kategori matematika, Indonesia berada di peringkat ke-7 dari bawah (73) dengan skor ratarata 379. Turun dari peringkat 63 pada tahun 2015. Sementara pada kategori kinerja sains, Indonesia berada di peringkat ke-9 dari bawah (71), yakni dengan rata-rata skor 396. Turun dari peringkat 62 pada tahun 2015.

Lebih lanjut dilakukan observasi terhadap perangkat pembelajaran guru di Gugus Kompyang Sujana. Dalam observasi yang dilakukan, ditemukan beberapa permasalahan. Pertama, 100\% guru belum memiliki instrumen penilaian IPA berbasis HOTS. Instrumen penilaian yang dimiliki oleh guru hanya berpatokan pada buku LKS dan paket. Jika dianalisis, soal-soal yang ada hanya mengacu pada keterampilan berpikir tingkat rendah karena hanya pada Mengingat (C1) dan memahami (C2). Kedua, 80\% guru belum mampu merancang sistem penilaian IPA berbasis HOTS. Ketiga, 100\% guru hanya mengandalkan tes objektif dalam menilai hasil belajar IPA siswa.

Permasalahan-permasalahan

tersebut perlu dicarikan solusinya agar tujuan pendidikan dalam Kurikulum 2013 dapat tercapai yaitu dengan mengembangkan sistem penilaian berbasis HOTS. Penilaian adalah salah satu tahap yang paling penting dalam pelaksanaan pendidikan untuk mengetahui kemampuan peserta didik.
Untuk itu, sistem penilaian IPA berbasis HOTS harus dimiliki oleh guru untuk melatih pemikiran tingkat tinggi siswa. Sistem penilaian ini tetap mengacu pada Permendikbud No 104 tahun 2014 tentang standar penilaian hasil belajar.

Ada dua alasan pengembangan ini. Pertama, sebagai upaya mempersiapkan peserta didik yang memiliki keterampilan berpikir tingkat tinggi. Dengan menggunakan penilaian berbasis HOTS, siswa tentu akan terbiasa dalam menjawab soal pada tingkatan ini. Hal ini diharapkan dapat meningkatkan kemampuan siswa dan daya saing siswa. Kedua, membantu melengkapi administrasi guru tentang sistem penilaian agar semua tingkat kognitif khususnya HOTS dapat diakomodasi. Sebelumnya, penilaian guru hanya pada $\mathrm{C} 1$ dan $\mathrm{C} 2$. Dengan instrumen ini tentu menjadi lengkap dan seimbang antar semua tingkatan kognitif.

Penelitian terkait pengembangan sistem penilaian berbasis HOTS dilakukan oleh Kholiq, Artharina, dan Arisyanto (2019). Hasil analisis soal yang digunakan dalam penilaian harian, penilaian tengah semester dan penilaian akhir semester semua kriteria penilaian pada setiap aspeknya hampir memenuhi, namun soal yang digunakan belum semuanya termasuk kategori soal HOTS karena terdapat soal yang hanya mengukur level kognitif tingkat rendah. Penilaian yang dilaksanakan telah memenuhi keseluruhan tahapan mulai dari perencanaan penilaian, mengembangkan instrumen penilaian, melaksanakan penilaian, memanfaatkan hasil penilaian serta melaporkan hasil penilaian dalam bentuk angka dengan skala 1-100 dan deskripsi.

Hasil penelitian tersebut menunjukan instrumen penilaian berbasis HOTS belum dibuat secara optimal. Untuk itu, penelitian ini dilakukan untuk menyempurnakan penelitian sebelumnya. Instrumen penilaian berbasis HOTS yang dikembangkan dalam penelitian ini memiliki beberapa karakteristiks. Pertama, soal-soal yang dikembangkan mengacu pada C4, C5 dan C6. Kedua, soal-soal yang dikembangkan berupa soal essay atau uraian. Ketiga, instrumen 
dikembangkan mengacu pada permasalahan-permasalahan kontekstual. Keempat, instrumen yag dikembangkan dibagi menjadi 3 berdasarkan jumlah subtema. Keempat hal tersebut menjadi kebaharuan dalam penelitian ini.

Ada dua rumusan masalah yang diteliti, a) bagaimanakah tingkat validitas instrumen penilaian berbasis HOTS pada pembelajaran IPA tema "Selamatkan Makhluk Hidup"? dan b) bagaimanakah tingkat kepraktisan instrumen penilaian berbasis HOTS pada pembelajaran IPA tema "Selamatkan Makhluk Hidup"?

Pengembangan instrumen penilaian berbasis HOTS pada pembelajaran IPA tema "Selamatkan Makhluk Hidup" penting dilakukan sebagai upaya perbaikan mutu pelayanan pendidikan bagi siswa. Secara spesifik, ada empat alasan pentingnya pengembangan ini dilakukan sebagai berikut.

Pertama, sampai saat ini, instrumen penilaian berbasis HOTS belum ada di sekolah-sekolah khususnya untuk tema "Selamatkan Makhluk Hidup". Dalam menilai hasil belajar siswa, para guru sekolah dasar umumnya hanya menggunakan tes-tes objektif yang ada di buku LKS (lembar kerja siswa). Hal ini tentu sudah usang bagi pendidikan modern seperti saat ini.

Kedua, tuntutan Kurikulum 2013 yang meminta satuan pendidikan mencetak generasi yang mampu berpikir kritis atau berpikir tingkat tinggi. Untuk itu, diperlukan instrumen penilaian yang mampu mengukur tingkat kemampuan berpikir kritis siswa yang mencakup tingkat kognitif : menganalisa (C4), mengevaluasi (C5) dan mencipta (C6).

Ketiga, sebagai upaya menghasilkan generasi yang sesaui tuntutan masyarakat industri 4.0 yang berorientasi pada keterampilan berpikir kritis dan inovasi. Dengan dihasilkannya produk berupa instrumen penilaian ini maka anak dilatih untuk berpikir tingkat tinggi. Anak diarahkan untuk mampu menganalisa suatu fenomena atau masalah, kemudian mengevaluasinya dan akhirnya mampu menghasilkan atau mencipta hal-hal baru dari materi yang dipelajari.
Keempat, memberikan suasana baru bagi siswa dalam sistem penilaian hasil belajar IPA. Selama ini ini, siswa hanya dijejali dengan tes-tes objektif dan kebanyakan berorientasi pada tingkat kognitif yang rendah yang mana dominan oleh hapalan. Hal ini tentu menjadi beban bagi siswa karena siswa kurang mendapatkan kesempatan untuk mengembangkan pemikiran kritisnya. Dengan dikembangkannya instrumen penilaian ini, maka siswa akan mendapatkan penyegaran dalam proses pendidikannya di sekolah.

\section{METODE}

Penelitian ini merupakan penelitian pengembangan dengan model ADDIE yang merupakan singkatan dari Analysis (analisa), Design (rancangan), Development (pengembangan), Implementatian (penerapan), Evaluation (evaluasi). Namun penelitian ini hanya dilakukan sampai tahap pengembangan saja karena pandemi Covid 19. Hal ini menyebabkan pembelajaran tatap muka tidak dapat dilakukan sehingga pengujian produk juga tidak dapat dilakukan.

Pada tahap analisis dilakukan analisis terhadap kebutuhan kurikulum. Ini mencakup tema, subtema, materi dan indikator. Hal pertama yang dilakukan adalah menelaah silabus kelas VI untuk mengetahui kompetensi dasar dan tema yang diangkat. Berdasarkan wawancara dengan guru, tema yang belum memiliki instrumen penilaian berbasis HOTS adalah "Menyelamatkan Makhluk Hidup". tema ini dibagi menjadi 3 subtema, yaitu : 1) tumbuhan sahabatku, 2) hewan sahabatku dan 3) ayo selamatkan hewan dan tumbuhan. Setelah tema dan subtema ditetapkan maka selanjutnya dilakukan pemetaan kompetensi dasar. Dari kompetensi dasar ini selanjutnya dioperasionalkan menjadi indikatorindikator yang mengukur tingkat kognitif menganalisis (C4), mengevaluasi (C5) dan mencipta (C6). Tahap perencanaan/rancangan ada tiga langkah, yaitu : a) penyusunan tes, b) pemilihan format, dan c) perancangan awal. Tahap pengembangan dilakukan dengan menguji draft soal-soal yang sudah dibuat 
sebelumnya. Tujuannya adalah untuk memperoleh masukan dari para ahli tentang validitas isi instrumen penilaian berbasis HOTS. Ahli yang ditunjuk berasal dari akademisi yang ahli dibidang sistem penilaian. Instrumen penilaian keterampilan berpikir tingkat tinggi terdiri dari 30 butir soal, dimana masing-masing subtema terdiri dari 10 soal. Semua soal merupakan soal essay. Soal-soal dikembangkan dari kisi-kisi yang telah dibuat sebelumnya. Pada tahap implementasi dilakukan ujicoba produk kepada 40 siswa kelas VI. Data ini selanjutnya dianalisis dengan formula Alpha Cronbach dan dikonfirmasi pada skala Guilford.

Subjek penelitian ini sebanyak 5 orang yang terdiri dari 2 akademisi (dosen) dan 3 praktisi (guru kelas VI). Ada dua instrumen yang digunakan, lembar penilaian kualitas produk dan kuesioner kepraktisan. Data yang dikumpulkan dianalisis secara deskriptif dengan mencari nilai rata-rata dan mentransformasinya ke dalam skala sebagai berikut.

Tabel 1. Skala Kategori Validitas

\begin{tabular}{cl}
\hline \multicolumn{1}{c}{ Nilai } & \multicolumn{1}{c}{ Kategori } \\
\hline $3,50 \leq R v \leq 4,00$ & Sangat Valid \\
$2,50 \leq R v \leq 3,50$ & Valid \\
$1,50 \leq R v \leq 2,50$ & Tidak Valid \\
$1,00 \leq R v \leq 1,50$ & Sangat tidak Valid \\
\hline
\end{tabular}

Tabel 2. Klasifikasi Guilford

\begin{tabular}{cl}
\hline Skor & \multicolumn{1}{c}{ Kriteria } \\
\hline $0,00-0,20$ & Sangat Tinggi \\
$0,20-0,40$ & Tinggi \\
$0,40-0,60$ & Sedang \\
$0,60-0,80$ & Rendah \\
$0,80-1,00$ & Sangat Rendah
\end{tabular}

Tabel 3. Skala Kategori Kepraktisan

\begin{tabular}{|c|c|}
\hline Nilai & Kategori \\
\hline $3,50 \leq R k \leq 4,00$ & $\begin{array}{l}\text { Sangat } \\
\text { layak }\end{array}$ \\
\hline $2,50 \leq R k \leq 3,50$ & Praktis/layak \\
\hline $1,50 \leq R k \leq 2,50$ & $\begin{array}{l}\text { Tidak praktis/tidak } \\
\text { layak }\end{array}$ \\
\hline $1,00 \leq R k \leq 1,50$ & $\begin{array}{ll}\text { Sangat } & \text { tidak } \\
\text { praktis/sangat } & \text { tidak } \\
\text { layak } & \end{array}$ \\
\hline
\end{tabular}

\section{HASIL DAN PEMBAHASAN}

Hasil penelitian

dan pembahasannya dapat dibagi dua bagian sesuai dengan jumlah rumusan masalah. Secara rinci dapat disajikan sebagai berikut.

\section{Validitas Instrumen Penilaian IPA berbasis HOTS}

Uji validitas dilakukan dengan uji ahli. Ada 2 ahli yang merupakan akademisi menilai kualitas instrumen penilaian IPA berbasis HOTS. Kedua ahli tersebut adalah ahli materi dan ahli sistem penilaian pendidikan. Penilaian dari masing-masing ahli kemudian dihitung rata-ratanya dan dicocokan dengan klasifikasi tingkat validitas seperti yang ditetapkan di sebelumnya. Hasil dari ketiga ahli dapat disajikan sebagai berikut.

\begin{tabular}{|c|c|c|c|}
\hline No & Aspek & $\begin{array}{l}\text { Rata- } \\
\text { rata }\end{array}$ & Kategori \\
\hline 1 & $\begin{array}{l}\text { Aspek } \\
\text { Materi }\end{array}$ & 5 & $\begin{array}{l}\text { Sangat } \\
\text { baik }\end{array}$ \\
\hline 2 & $\begin{array}{l}\text { Aspek } \\
\text { Bahasa }\end{array}$ & 4,78 & $\begin{array}{l}\text { Sangat } \\
\text { baik }\end{array}$ \\
\hline 3 & $\begin{array}{l}\text { Aspek } \\
\text { Konstruksi }\end{array}$ & 4,84 & $\begin{array}{l}\text { Sangat } \\
\text { baik }\end{array}$ \\
\hline \multicolumn{2}{|c|}{ Rata-rata } & 4,89 & $\begin{array}{l}\text { Sangat } \\
\text { baik }\end{array}$ \\
\hline
\end{tabular}

Berdasarkan Tabel 4, nilai rata-rata aspek materi sebesar 5 yang terkategori sangat baik, nilai rata-rata aspek bahasa sebesar 4,78 dengan kategori sangat baik dan nilai rata-rata aspek konstruksi sebesar 4,84 dengan kategori sangat baik. Ini berarti rata-rata validitas instrumen sebesar 4,89 dengan kategori sangat baik. Pengujian validitas isi bertujuan untuk melihat elemen-elemen yang ada dalam alat ukur (Coaley, 2010). Dengan demikian dapat diketahui jangkaun instrumen penilaian dalam mengukur aspek yang hendak diukur. Dalam pengukuran validitas isi, analisis rasional adalah proses utama yang dilakukan dalam analisis validitas isi (Azwar, 2005).

Setelah instrumen penilaian dinyatakan valid dari segi isi, selanjutnya dilihat validitas dari segi materi, bahasa dan konstruksi. Berdasarkan hasil analisis 
terhadap instrumen penilaian, dimensi materi mendapat rata-rata nilai 5 yang terkategori sangat tinggi, dimensi bahasa mendapat rata-rata nilai 5 yang terkategori sangat tinggi dan dimensi konstruksi mendapat rata-rata nilai 5 yang terkategori sangat tinggi. Ini berarti instrumen penilaian yang dikembangkan sudah memenuhi syarat yang ditetapkan oleh Permendikbud Nomor 8 Tahun 2016.

Dari segi isi, pengembangan instrumen penilaian berbasis keterampilan berpikir tingkat tinggi sudah sesuai dengan tuntutan Kurikulum 2013 edisi revisi 2017 dengan menekankan pada C4,C5 dan C6. Hal ini dilakukan sebagai upaya untuk menghasilkan output yang memiliki kemampuan berpikir kritis dan analitis sesuai tuntutan abad 21 (Pappas, Pierakos dan Nagel, 2012). Lebih lanut pengembangan instrumen daris segi isi juga sudah sesuai dengan tahap perkembangan psikologi siswa. Soemanto (2006) menyatakan bahwa perancangan tes yang sesuai dengan perkembangan kognitif siswa dapat memberikan gambaran yang tepat tentang IQ siswa.

Dari segi bahasa, instrumen yang dikembangkan sudah menggunakan bahasa yang jelas dan sederhana. Pemilihan ini karena tes dikerjakan oleh anak sekolah dasar sehingga bahasa yang digunakan hanya bahasa yang sederhana. Dengan bahasa yang sederhana, siswa dapat memahami substansi tes dan apa yang diminta oleh tes. Basuki dan Hariyanto (2015) menyatakan bahwa tes yang baik sesaui dengan kaidah kebahasaan yang baku dan komunikatif. Untuk itu, bahasa tes harus disesuaikan dengan tingkat perkembangan kognitif siswa agar mudah dipahami sehingga terjadi komunikasi antara pembuat tes dan siswa.

Dari segi konstruksi, instrumen penilaian IPA berbasis kemampuan berpikir tingkat tinggi menggunakan format yang sistematis. Dalam setiap soal, siswa diberikan stimulus terlebih dahulu yang selanjutnya diberikan pertanyaan atau pernyataan. Struktur soal ada yang menggunakan pertanyaan dan pernyataan dalam bentukkalimat perintah. Agar siswa lebih mudah menggunakan tes maka ada petunjuk yang disediakan. Selain itu, tes juga dilengkapi dengan rubrik penskoran. Suharsimi (2007) menyatakan tes atau instrumen penilaian harus lengkap dari butir soal, petunjuk dan cara penskorannya.

Berdasarkan penjelasan tersebut maka instrumen penilaian IPA berbasis keterampilan berpikir tingkat tinggi terkategori valid. Dengan demikian, menurut Ahmad, dkk (2018) instrumen ini sudah layak digunakan. Instrumen ini selanjutnya dapat digunakan dalam pembelajaran di sekolah untuk menilai tingkat berpikir kritis siswa.

Hasil penelitian ini sejalan dengan Fitriani, Suryana dan Hamdu (2018). Alhasilnya instrumen penilaian HOTS yang dikembangkan terkategori valid dan reliabel. Hal senada juga ditemukan oleh Alfiatin dan Oktiningrum (2019) yang mengembangkan sistem penilaian HOTS untuk pelajaran matematika. Penelitian ini juga menemukan instrumen penilaian yang dikembangkan valid dan reliable sehingga layak digunakan untuk mengukur keterampilan berpikir tingkat tinggi siswa.

\section{Reliabilitas Instrumen Penilaian IPA berbasis HOTS}

Uji reliabilitas instrumen dilakukan dengan mengujicobakan instrumen kepada siswa. Uji coba dilakukan pada siswa kelas 6 dengan melibatkan 40 siswa. Uji coba dilakukan 3 tahap karena jumlah soal ada 30 yang dibagi menjadi 3 subtema. Pelaksanaan uji coba dilakukan secara daring. Jawaban siswa diskor dan ditabulasi. Selanjutnya dianalisis dengan formula Alpha Cronbach yang tersedia pada SPSS 16 for Windows.

Tabel 5. Hasil Uji Kepraktisan

Reliability Statistics

\begin{tabular}{rr}
\hline Cronbach's Alpha & N of Items \\
\hline .811 & 30 \\
\hline
\end{tabular}

Berdasarkan Tabel 5, dapat diketahui nilai Alpha Cronbach sebesar 0,811 . Berdasarkan klasifikasi Guilford nilai tersebut terkategori tinggi. Dengan demikian, instrumen penilaian IPA 
berbasis HOTS terkategori reliabel. Ini berarti instrumen penilaian yang dikembangkan mempunyai keterpercayaan, keterandalan, keajegan, konsistensi, kestabilan yang dapat dipercaya (Azwar, 2011).

Instrumen penilaian yang reliabel tentu dapat dipercaya hasilnya karena memiliki nilai yang relatif sama atau hasil yang konsisten pada berbagai pengukuran (Neuman, 2007). Ini memberikan tingkat kepercayaan yang tinggi kepada pengguna instrumen penilaian. Pengguna tentu tidak akan ragu dengan hasil yang didapat dengan menggunakan instrumen ini.

Hasil penelitian ini sejalan dengan penelitian yang dilakukan oleh Budiman dan Jailani (2014). Hasil penelitian menunjukkan bahwa instrumen asesmen HOTS berupa soal tes HOTS yang terdiri dari 24 butir soal pilihan ganda dan 19 butir soal uraian dari aspek materi, konstruksi, dan bahasa dinyatakan valid dan layak digunakan. Instrumen tersebut mempunyai koefisien reliabilitas sebesar 0,713 (soal pilihan ganda) dan sebesar 0,920 (soal uraian).

Selain itu, hasil penelitian ini juga sejalan dengan penelitian Alfiatin dan Oktiningrum (2019). Berdasarkan hasil penelitian, diperoleh instrumen tes yang valid, dengan kriteria tinggi yaitu 4,33 dan reliabel dengan kriteria tinggi yaitu nilai 0,85 . Dari field test, hasil rata-rata kemampuan penalaran siswa 67,85 dengan kategori cukup., terdapat 7 siswa (25\%) memiliki kemampuan penalaran sangat baik, 7 siswa (25\%) memiliki kemampuan penalaran baik, 3 siswa $(10,71 \%)$ memiliki kemampuan penalaran cukup, dan 11 siswa (39,29\%) memiliki kemampuan penalaran kurang.

\section{Kepraktisan Instrumen Penilaian IPA berbasis HOTS}

Uji kepraktisan dilakukan dengan meminta pendapat 2 praktisi atau guru kelas VI. Hasil analisis dapat disajikan sebagai berikut.
Tabel 6. Hasil Uji Kepraktisan

\begin{tabular}{llcl}
\hline No & Aspek & $\begin{array}{l}\text { Rata- } \\
\text { rata }\end{array}$ & Kategori \\
\hline 1 & Kemudahan & 4,94 & $\begin{array}{l}\text { Sangat } \\
\text { Praktis }\end{array}$ \\
2 & Kegunaan & 4,88 & $\begin{array}{l}\text { Sangat } \\
\text { Praktis }\end{array}$ \\
3 & Daya Tarik & 4,94 & $\begin{array}{l}\text { Sangat } \\
\text { Praktis }\end{array}$ \\
\hline Rata-Rata & 4,92 & $\begin{array}{l}\text { Sangat } \\
\text { Praktis }\end{array}$ \\
\hline
\end{tabular}

Tabel 6 menunjukan bahwa nilai rata-rata aspek kemudahan sebesar 4,94 dengan kategori sangat praktis, nilai ratarata aspek kegunaan sebesar 4,88 dengan kategori sangat praktis dan nilai rata-rata aspek daya tarik sebesar 4,94 dengan kategori sangat praktis. Dengan demikian, instrumen penilaian berpikir tingkat Tinggi IPA kelas VI terkategori praktis atau layak digunakan. Yusuf (2005) menyatakan pengujian kepraktisan instrumen penilaian untuk melihat kemudahan penggunaan instrumen dengan ciri-ciri : mudah dilaksanakan, tidak menuntut peralatan yang banyak dan memberi kebebasan kepada audiens mengerjakan yang dianggap mudah terlebih dahulu.

Uji kepraktisan mencakup tiga aspek, yaitu: kemudahan, kegunaan dan daya tarik. Untuk aspek kemudahan dapat dilihat dari efisiensi, mudah dalam penggunaan dan kesederhanaan instrumen. Dilihat dari efisiensi, instrumen yang dikembangkan efisien menilai kemampuan berpikir tingkat tinggi siswa dalam pelajaran IPA. Hal ini dapat dilihat dari rubrik penskoran yang sudah disediakan. Pengguna cukup mencocokan jawaban siswa dengan rubrik penskoran dalam memberikan nilai kepada siswa. Dalam penggunaanya juga mudah karena sudah dilengkapi dengan petunjuk pengerjaan tes. Suharsimi (2002) menyatakan tes menjadi praktis jika sudah dilengkapi rubrik penskoran. Instrumen penilaian juga dirancang sederhana dimulai dari stimulus dan soal. Stimulus dapat berupa pernyataan dan gambargambar ilustrasi. 
Dalam hal kegunaan, instrumen penilaian IPA berbasis keterampilan berpikir tingkat tinggi sudah sesuai dengan tuntutan kurikulum 2013. Ini berarti instrumen dapat digunakan untuk mengukur kemampuan siswa pada subtema ini. Selain itu, tingkat kognitif yang diuji sudah sesuai dengan keterampilan berpikir tingkat tinggi, yaitu: C4, C5 dan C6. Tingkatan kognitif tersebar di setiap subtema. Dengan demikian, guru dapat langsung menggunakan instrumen ini untuk mengukur keterampilan berpikir tingkat tinggi siswa. instrumen penelitian ini juga dirancang dengan mempertimbangkan perkembangn kognitif siswa yaitu siswa sekolah dasar. Dengan demikian, soal-soal tidak terlalu sulit bagi siswa.

Dalam hal daya tarik, pengembangan instrumen penilaian menggunakan permasalahan dunia nyata atau hal-hal yang sifatnya kontekstual. Materi dalam tes dipilih agar dekat dengan kehidupan siswa sehingga siswa menjadi lebih mudah memahami permasalahan. Selain itu, tes juga dilengkapi dengan stimulus baik dengan gambar maupun narasi agar dapat memotivasi siswa mengerjakan soal.

Pengujian kepraktisan suatu produk perlu dilakukan untuk menjamin bahwa produk yang dihasilkan tidak menimbulkan permasalahan dalam penggunaannya (Dachi dan Perdana, 2020). Permasalahan ini umunya karena kurang lengkapnya komponen instrumen penilaian dan juga instrumen ribet digunakan. Dengan bukti dari para guru bahwa instrumen praktis berarti instrumen penilaian IPA keterampilan berpikir tingkat tinggi tidak menimbulkan dalam pelaksanaannya.

Hasil penelitian dan pengembangan ini menghasilkan tiga implikasi. Pertama, pengembangan instrumen penilaian IPA berbasis keterampilan berpikir tingkat tinggi harus dimulai dari analisis kebutuhan di lapangan. Hal ini agar pengembangan yang dilakukan tidak mubazir. Setelah analisis kebutuhan dilakukan maka selanjutnya analisis kompetensi dasar dan pengembangan indikator agar sesuai tingkatan kognitif berpikir tingkat tinggi. Dengan ini maka instrumen yang dikembangkan sesuai dengan kebutuhan di lapangan.

Kedua, selain berpatokan pada kebutuhan, penyesuaian materi dalam instrumen juga harus disesuaikan dengan keadaan saat ini. Dengan demikian, sistem penilaian mampu mengukur tingkat kemampuan siswa terhadap isu-isu mutahir yang terjadi. Materi yang diujikan dalaminstrumen hendaknya yang mutahir atau sesuai dnegan permasalahan otentik saat ini. Dengan demikian, siswa menjadi lebih tertarik dan termotivasi belajar.

Ketiga, pengembangan instrumen penilaian berbasis keterampilan berpikir tingkat tinggi hendaknya mengacu pada kepraktisan penggunaan. Hal ini mengingat beban mengajar guru dan jumlah siswa yang sering tidak sesuai dengan rasio guru dan siswa. Untuk itu, kelengkapan instrumen penilaian harus benar-benar diperhatikan. Selain itu, jumlah soal dan ekspektasi jawaban juga harus diperhatikan agar tidak membebani guru terlalu banyak.

\section{PENUTUP}

Berdasarkan hasil analisis secara deskriptif maka ada dua simpulan yang dibuat. Pertama, instrumen penilaian IPA berbasis HOTS yang dikembangkan secara umum terkategori sangat valid dengan skor rata-rata 4,89. Secara spesifik, nilai rata-rata aspek materi sebesar 5 yang terkategori sangat baik, nilai rata-rata aspek bahasa sebesar 4,78 dengan kategori sangat baik dan nilai ratarata aspek konstruksi sebesar 4,84 dengan kategori sangat baik. Kedua, instrumen penilaian IPA berbasis HOTS memiliki nilai reliabilitas tinggi dengan koefisien alpha sebesar 0,811. Ketiga, instrumen penilaian IPA berbasis HOTS yang dikembangkan terkategori sangat praktis bagi guru dengan nilai rata-rata 4,92 . Secara spesifik, nilai rata-rata aspek kemudahan sebesar 4,94 dengan kategori sangat praktis, nilai rata-rata aspek kegunaan sebesar 4,88 dengan kategori sangat praktis dan nilai rata-rata aspek daya tarik sebesar 4,94 dengan kategori sangat praktis. 
Dari hasil ini maka ada beberapa saran yang diberikan kepada pihak-pihak terkait, yaitu: siswa, guru, kepala sekolah dan peneliti lain. Siswa disarankan untuk mengerjakan soal-soal dalam instrumen penilaian yang dikembangkan dengan serius. Jika mengalami kesulitan dapat bertanya kepada guru. Hal ini perlu dilakukan agar didapat tigkat keterampilan berpikir tingkat tinggi siswa secara akurat. Guru disarankan untuk lebih banyak memberikan latihan soal yang berorientasi keterampilan berpikir tingkat tinggi. Instrumen yang dikembangkan dapat dijadikan instrumen penilaian alternatif untuk latihan soal IPA pada tema "selamatkan makhluk hidup". Peneliti lain dapat melanjutkan penelitian ini dengan melakukan tahap implementasi dan evaluasi untuk instrumen yang dikembangkan ini. Kepala sekolah disarankan untuk memfasilitasi para guru untuk membuat instrumen penilaian berbasis keterampilan berpikir tingkat tinggi. Kepala sekolah dapat mengundang tim ahli dari kampus atau dinas untuk menjadi fasilitator atau pemateri. Dengan demikian, guru mampu memenuhi ekspektasi pemerintah yang ingin menetapkan target siswa harus memiliki kemampuan berpikir tingkat tinggi yang baik.

\section{DAFTAR RUJUKAN}

Abdullah, (1998). Pembelajaran IPA di SD. Jakarta : Universitas Terbuka.

Ahmad, dkk. (2018). Studi Tentang Prestasi Belajar Siswa Dalam Berbagai Aspek Dan Faktor Yang Mempengaruhi. Jurnal Komunikasi Pendidikan. 2(2) : 115-123

Alfiatin, Aina Lutfi dan Oktiningrum, Wuli. (2019). Pengembangan Soal Higher Order Thinking Skills Berbasis Budaya Jawa Timur Untuk Mengukur Penalaran Siswa SD. INDIKTIKA (Jurnal Inovasi Pendidikan Matematika). Vol 2(1), hal. 30-43

Anderson, L.W. \& Krathwohl, D.R. (Eds.) (2001). A taxonomy for Learning, teaching, and assessing: A revision of Bloom's taxonomy of educational objectives. New York: Addison Wesley Longman

Arikunto, Suharsimi. (2005). Dasar-Dasar Evaluasi Pendidikan. Jakarta: Bumi Aksara

Azwar, S. (2005). Dasar-Dasar Psikometri. Yogyakarta: Pustaka Pelajar.

Barak, M.,\& Dori, Y. J. (2009). Enhancing Higher Order Thinking Skills Among Inservice Science Teachers Via Embedded Assessment.Journal of Science Teacher Education,20(5), 459-474.

Basuki, Ismet dan Hariyanto. (2015). Asesmen Pembelajaran. Bandung: PT. Pemaja Rosdakarya.

Chalkiadaki, Areti. (2018). A Systematic Literature Review of 21st Century Skills and Competencies in Primary Education. International Journal of Instruction. Vol 11(3), hal. 1-16. https://doi.org/10.12973/iji.2018.113 $\underline{1 \mathrm{a}}$

Coaley, K. (2010). An Introduction To Psychological Assessment And Psychometrics.London: Sage Publication Ltd.

Fitriani, Desi., Suryana, Yusuf dan Hamdu, Ghullam. (2018). Pengembangan Instrumen Tes Higher-Order Thinking Skill pada Pembelajaran Tematik Berbasis Outdoor Learning di Sekolah Dasar Kelas IV. IJPE. Vol 2(1), tersedia pada https://ejournal.upi.edu/index.php/IJ PE/article/view/13752

Helmawati. 2019. Penilaian dan Pembelajaran Berbasis HOTS. Bandung: Remaja Rosdakarya Offset.

Khotimah, Khusnul. (2019). Pengembangan Evaluasi Pembelajaran berbasis Higher Order Thinking Skill di Sekolah Dasar. 
Proceeding pada Seminar Nasional Pendidikan FKIP UNMUL I. Samarinda, 24 Agustus 2019

Kholiq, Hisyam Abdul., Artharina, Filia Prima dan Arisyanto, Prasena. (2019). Analisis Penilaian Berorientasi Higher Order Thinking Skills siswa Kelas V. Janacitta, vol 2(2), tersedia pada http://jurnal.unw.ac.id:1254/index.ph p/janacitta/article/view/259

King,F., Goodson, L., \& Rohani, F. (2011). Higher Order Thinking Skills: Assessment and Evaluation. California, USA: Center for Advandcement of Learning and Assessment.

Pappas,E., Pierakos,O dan Nagel, R. (2012). Using Bloom's Taxonomy to Teach Sustainability in Multiple Contexts. Elsevier. Tersedia pada https://www.researchgate.net/publica tion/257408770 Using Bloom\%27s Taxonomy to teach sustainability in multiple contexts

Soemanto,Wasty.2006. Psikologi Pendidikan Landasan Kerja Pemimpin Pendidikan. Jakarta: Rineka Cipta

Sunarti dan Rahmawati, S. (2014). Penilaian dalam Kurikulum 2013. Yogyakarta: Andi Offset.

Widodo, T. dan Kadarwati, S. (2013). High order thingking berbasis pemecahan masalah untuk meningkatkan hasil belajar berorientasi pembetukan karakter siswa. Cakrawala Pendidikan, 32(1): 161-171.

Yusuf. A.Muri. (2005). Metodologi Penelitian (Dasar-Dasar Penyelidikan IImiah). Padang: UNP Press 